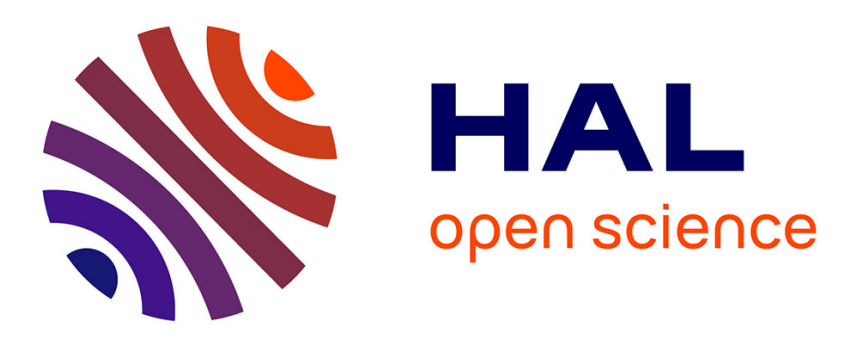

\title{
Evolution of the genetic variability of eight French dairy cattle breeds assessed by pedigree analysis
}

Coralie Danchin-Burge, Grégoire Leroy, M. Brochard, S. Moureaux, Etienne Verrier

\section{- To cite this version:}

Coralie Danchin-Burge, Grégoire Leroy, M. Brochard, S. Moureaux, Etienne Verrier. Evolution of the genetic variability of eight French dairy cattle breeds assessed by pedigree analysis. Journal of Animal Breeding and Genetics, 2012, 129 (3), pp.206-217. 10.1111/j.1439-0388.2011.00967.x . hal-00999874

\section{HAL Id: hal-00999874 https://hal.science/hal-00999874}

Submitted on 18 Jun 2014

HAL is a multi-disciplinary open access archive for the deposit and dissemination of scientific research documents, whether they are published or not. The documents may come from teaching and research institutions in France or abroad, or from public or private research centers.
L'archive ouverte pluridisciplinaire HAL, est destinée au dépôt et à la diffusion de documents scientifiques de niveau recherche, publiés ou non, émanant des établissements d'enseignement et de recherche français ou étrangers, des laboratoires publics ou privés. 


\title{
Evolution of the genetic variability of 8 French dairy cattle breeds assessed by pedigree analysis
}

\author{
Coralie Danchin-Burge ${ }^{1,2,3}$, Grégoire Leroy ${ }^{1,2}$, Mickaël Brochard ${ }^{3}$, \\ Sophie Moureaux ${ }^{3}$, Etienne Verrier ${ }^{1,2}$
}

${ }^{1}$ AgroParisTech, UMR 1313 Génétique Animale et Biologie Intégrative, 75005 Paris, France 2INRA, UMR 1313 Génétique Animale et Biologie Intégrative, 78350 Jouy-en-Josas, France 'Institut de l'Elevage, 75012 Paris, France

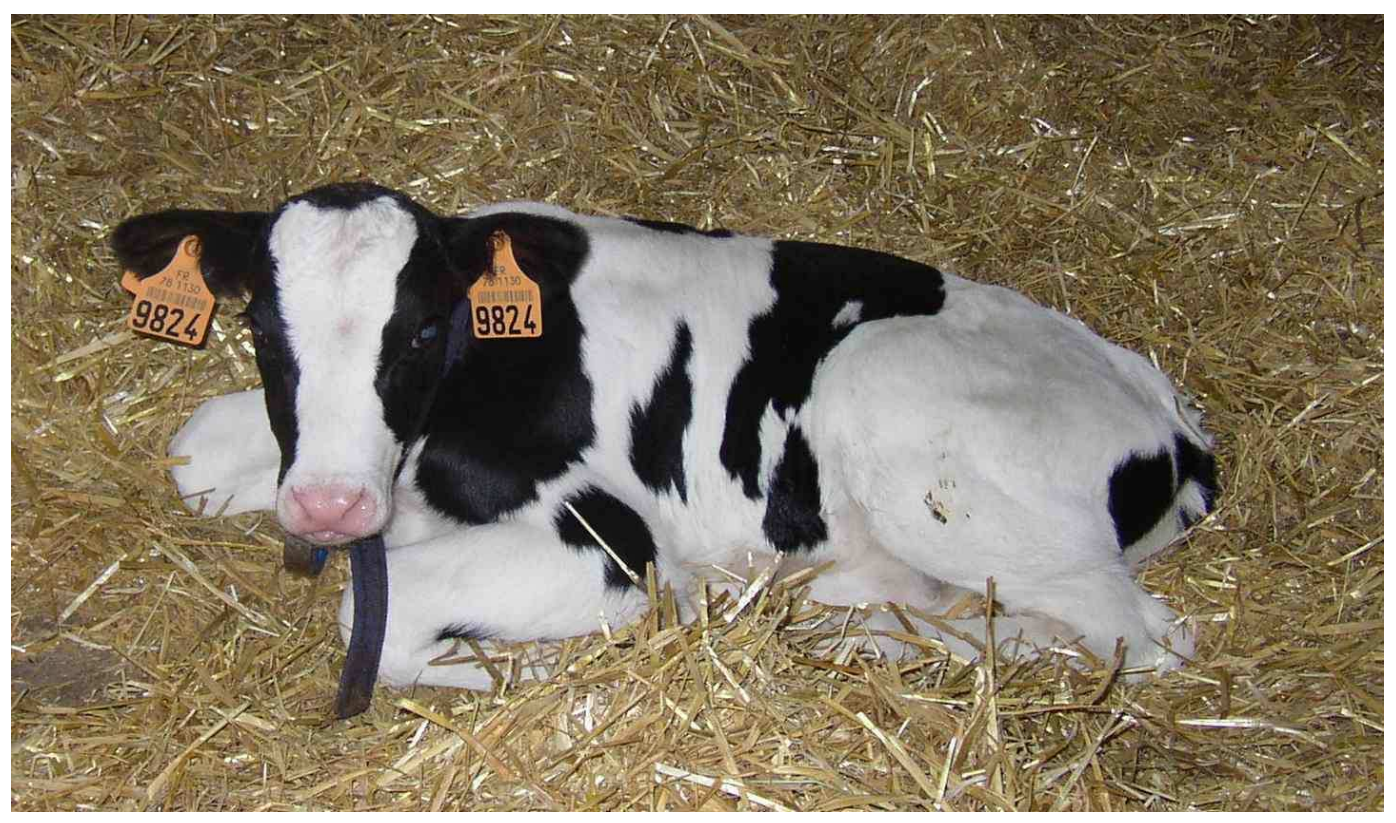

To maintain a sufficient amount of within-population genetic variability is required, in order to allow the future generations of animals to be more and more adapted to changing environmental conditions and breeding goals.

Female calf from the Holstein breed born in the AgroParisTech experimental farm Photo: Emmanuelle Bourgeat 


\section{Summary}

A pedigree analysis was performed on eight French dairy cattle breeds in order to assess their change in genetic variability since a first analysis completed in 1996. The Holstein, Normande and Montbéliarde breeds are selected internationally with over hundreds of thousands cows registered in the performance recording system. Three breeds are internationally selected but with limited numbers of cows in France (Brown-Swiss, French Simmental and French Red Pied). The last two remaining breeds (Abondance and Tarentaise) are raised at regional level. The effective numbers of ancestors of cows born between 2004 and 2007 varied between 15 (Abondance and Tarentaise) and 51 (French Red Pied). The effective population sizes (classical approach) varied between 53 (Abondance) and 197 (French Red Pied). This article also compares the genetic variability of the ex situ (collections of the French national Cryobank) and in situ populations. The results were commented in regards with the recent history of gene flows in the different breeds as well as the existence of more or less stringent bottlenecks. Our results showed that whatever the size of the breeds, their genetic diversity impoverished quite rapidly since 1996 and they all could be considered as quite poor from a genetic diversity point of view. It shows the need for setting up cryobanks as gene reservoirs as well as sustainable breeding programs that include loss of genetic diversity as an integrated control parameter.

\section{Keywords}

genetic diversity, dairy cattle, French breeding schemes, pedigree information, cryobank 


\section{Introduction}

During the last forty years, breeding programs in developed countries contributed to major changes in the mean values of the dairy cattle populations for a series of traits (e.g. Philipsson et al., 2009): spectacular increase of milk yield, increase of both fat and protein contents, increase of adult size, improvement of udder morphology, decrease of female fertility, etc. Several factors allowed the selection each year of a few bulls, each one having a very large number of offspring: a strong collective organization of breeders, the development of on farm dairy recording, procedures leading to the genetic evaluation of young bulls with a high accuracy (progeny testing and, now, genomic evaluation), and the efficiency and the vastly diffusion possibilities offered by Artificial Insemination (AI).

It is necessary to maintain a sufficient amount of within-population genetic variability, in order either to go on selecting the dairy traits or to improve functional traits, as well to preserve a "core of genes" for traits we might need in the future but that cannot be foreseen. For the Holstein breed, results obtained in different countries, with various indicators, showed that managing the genetic variability of this worldwide breed deserves much attention (e.g., Van Doormaal et al., 2005; Koenig et al., 2006; Kim and Kirkpatrick, 2009; Danchin-Burge et al., 2011). It is also needed to monitor the genetic variability within other dairy cattle breeds, as revealed by recent pedigree analyses (e.g., Baumung and Sölkner, 2002; Sørensen et al., 2005; Mattalia et al., 2006; Mc Parland et al., 2007).

In the short term, the most effective way to preserve the genetic variability in a selected population is to implement a method intended to optimize the genetic gain on some traits under a restricted rate of inbreeding (Meuwissen, 1997) or to minimize the rate of inbreeding under the condition of a given genetic gain (Colleau et al., 2004). The genetic variability of livestock breeds can also be preserved thanks to the conservation of biological material (semen and embryos mostly) frozen in liquid nitrogen (DanchinBurge et al., 2006). This is the main reason for the creation of national cryobanks for livestock species in some countries such as the Netherlands (1993) the USA (1999) and France (1999). For instance, six of the eight main French dairy cattle breeds are part of the collections of the French cryobank (for a permanent inventory update, see www.cryobank.org).

In the present paper, the situation of the eight main French dairy cattle breeds will be analyzed in details. Emphasis will be put on $(i)$ the evolution of the within-population genetic variability over time by comparison to previous studies on the same breeds and (ii) the comparison of the current populations with the ex situ collections that exist in the French cryobank. Indicators based on pedigree data will be used for this study. They allow the assessment of the within-population genetic variability in terms of probabilities of gene origin and of gene identity, the results being valid for any neutral locus without mutation (see, e.g. Boichard et al., 1997; Baumung et al., 2003; Fernandez et al., 2005). 


\section{Material and Methods}

\section{Populations Studied and data available}

Among the various dairy cattle breeds raised in France, eight of them benefit from a breeding program, with progeny testing of young bulls issued of selective matings. Some characteristics of these breeds are shown in Table 1, breeds being ranked by decreasing population size. The Holstein breed (HOL) is the main French dairy cattle breed and is raised in almost all the territories. The Montbéliarde (MON) and Normande (NOR) breeds originate from two different French regions and show different figures: in the last decades, the population size of MON increased whereas the NOR decreased. At present, MON is raised in a large majority of the territory whereas NOR is mainly raised in Normandy. Three other breeds, namely the Brown-Swiss (BSW), the Simmental (SIM) and the Red Pied (FRP) breeds, are the French nuclei of international breeds and are mainly raised in one or two French regions. The Abondance (ABO) and Tarentaise (TAR) breeds are hardy breeds mainly raised in the French Northern Alps, the farming system involving transhumance between valley and high altitude pastures (Verrier et al., 2005).

For all these breeds, there is a high number of cows with performance recording (Table 1) and $\mathrm{AI}$ is the almost exclusive breeding way. Among these breeds, two are completely closed populations (NOR and TAR), the breeding program of two of them has included the use of North-American Red Holstein bulls for a brief period (in the 80s for the ABO and in the late 70s for the MON), and the programs of the last four breeds (BSW, FRP, SIM, HOL) include the wide extent use of bulls born in several foreign countries.

For breeds benefiting from an organized selection program (in contrast with rare breeds), the aim of the French cryobank is to preserve the future possibilities for a given population to change its breeding goals, by keeping available representative samples of the different populations at different periods (Danchin-Burge et al., 2006). By January 2009 , the cattle species was represented in the cryobank by the semen doses of 750 bulls from a total of 23 different breeds, including six breeds among the eight studied here: HOL (152), MON (105), NOR (165), BSW (25), ABO (48) and TAR (53).

All the pedigree information came from the French national cattle database, called "Système d'Information Génétique" (SIG) which is used for the national genetic evaluation. The total number of animals in the file is given in Table 1. The data available for this article are similar to the ones used in previous studies dealing with these eight French breeds, see for more details Maignel et al., 1996; Moureaux et al., 2000; and Mattalia et al., 2006. 
Table 1: Demographic characteristics, pedigree depth and generation intervals (for parents born in 1998-2002) for the eight dairy cattle breeds under study

\begin{tabular}{|c|c|c|c|c|c|c|c|}
\hline Breed & Code & $\begin{array}{l}\text { No. of milk } \\
\text { recorded } \\
\text { cows (2009) }\end{array}$ & $\begin{array}{l}\text { Total size of } \\
\text { the pedigree } \\
\text { file }\end{array}$ & $\begin{array}{l}\text { Size of the } \\
\text { reference } \\
\text { population } \\
\text { (females) and } \\
\text { pedigree depth } \\
\text { (2004/2007) }\end{array}$ & $\begin{array}{c}\text { No. of CBN } \\
\text { bulls, pedigree } \\
\text { depth and age in } \\
2007\end{array}$ & $\begin{array}{c}\text { No. of active } \\
\text { bulls, pedigree } \\
\text { depth and age in } \\
2007\end{array}$ & $\begin{array}{c}\text { Generation } \\
\text { interval }\end{array}$ \\
\hline Holstein & HOL & $1,758,394$ & $20,109,663$ & $2,099,307 / 7.9$ & $152 / 9.1 / 8.5$ & $303 / 7.2 / 6.6$ & 5.6 \\
\hline Montbéliarde & MON & 407,223 & $3,322,397$ & $450,214 / 7.1$ & $105 / 6.5 / 8.4$ & $92 / 6.5 / 7.2$ & 6.2 \\
\hline Normande & NOR & 247,200 & $3,501,019$ & $329,272 / 8.3$ & $165 / 7.5 / 9.0$ & $41 / 7.3 / 6.9$ & 6.0 \\
\hline Abondance & $\mathrm{ABO}$ & 22,031 & 182,230 & $18,910 / 5.5$ & $48 / 5.3 / 8.0$ & $13 / 5.3 / 7.8$ & 7.0 \\
\hline Brown-Swiss & BSW & 17,606 & 156,533 & 19,266 / 5.8 & $25 / 5.3 / 7.6$ & $9 / 5.6 / 7.8$ & 6.5 \\
\hline French Simmental & SIM & 15,308 & 170,565 & $18,383 / 5.3$ & l & $20 / 4.6 / 7.1$ & 5.7 \\
\hline French Red Pied & FRP & 9,915 & 144,565 & $11,271 / 5.9$ & l & $8 / 5.0 / 7.9$ & 6.5 \\
\hline Tarentaise & TAR & 7,284 & 73,937 & $6,594 / 5.5$ & $53 / 4.8 / 8.5$ & $15 / 4.7 / 8.4$ & 7.5 \\
\hline
\end{tabular}


In order to compare the ex situ and in situ genetic variability of the breeds under study, we extracted the list of all the cryobank dairy cattle bulls (CBN) in the cryobank database till January 2009. To push further the genetic variability analysis we sampled from the SIG database a population of Active Males (AM) with the following criteria: each bull had to be born in France; both parents of the bull were known; each bull had doses sold by a French breeding company during the 2005/2007 period. Some bulls can be part of both male populations, i.e. CBN and AM. The average age in 2007 of the male reference populations (CBN and $\mathrm{AM}$ ) was also calculated.

\section{Analysis of Genetic Variability}

By using the PEDIG software (http://www6.jouy.inra.fr/gabi_eng/Our-resources/Tooldevelopment/Pedig, Boichard 2002), we estimated the genetic variability of each reference population and its evolution over time.

Pedigree depth and indicators computed from the theory of the probabilities of gene origin were analyzed for a female reference population of animals $\left(\mathrm{F}_{\mathrm{ref}}\right)$, i.e. cows born from 2004 to 2007 with both parents known, and for two male populations (AM and CBN). The principles of the methods are described in detail in Boichard et al. (1997) and a view on how they can be applied to livestock breeds is available in several publications (Baumung and Sölkner, 2002; Danchin-Burge et al., 2010). Pedigree depth is described by the equivalent generation number $\left(E q G_{i}\right)$ determined for each animal (i). The $E q G$ for each population was computed as the mean of the $E q G_{i}$. The generation intervals on the four pathways were estimated as the average birth year difference between parents born in the period 1998-2002 and their reproducing offspring, i.e. offspring having themselves at least one offspring known in the database. The average generation interval for each population is defined as the average of the four pathways (Lacy, 1989).

A strong assumption of the whole data analysis is that all founders (i.e. animals with offspring and unknown parents) are non-inbred and non-related. The effective number of founders $\left(f_{e}\right)$ and ancestors $\left(f_{a}\right)$ and number of ancestors contributing the most for a cumulated expected contribution of $50 \%$ of the genes $\left(N_{50}\right)$ as defined by Boichard et al. (1997) were calculated for the three reference populations ( $\mathrm{F}_{\text {ref, }} \mathrm{AM}$ and $\mathrm{CBN}$ ). The $f_{e} / f_{a}$ ratio can be used to appreciate the impact of the bottlenecks that have occurred from the founders to the present population (Boichard et al., 1997): the higher the $f_{e} / f_{a}$ ratio, the more stringent the bottlenecks. The effective number of ancestors calculated with our female reference population will be compared with results calculated on female reference populations born in the periods 1988-1991 (Maignel et al.,1996), 1993-1996 (Moureaux et al. 2001), and 2000-2003 (Mattalia et al. 2006) respectively.

The evolution of the contributions of the different original gene pools in breeds in which gene introgressions have occurred during a long period (HOL, BSW, SIM and FRP) or on a short period only (MON, ABO) was assessed by using the probability of gene origin and attributing a country or breed of origin to each founder. The contributions were calculated for all the females with two parents known born between 1980 and 2007 included, and averaged by birth year. 
The coefficient of inbreeding of each animal in the file was computed by the method of Meuwissen and Luo (1992). The rate of inbreeding per generation $(\Delta F)$ was estimated by using two methods. First, $\Delta F$ was computed on the basis of the classical formula (see, e.g., Falconer \& Mackay 1996):

$$
\Delta F=\frac{F_{t+1}-F_{t}}{1-F_{t}}
$$

where $F_{t}$ is the average coefficient of inbreeding at generation $t$. The values of $F_{t}$ and $F_{t+1}$ were computed by simply multiplying the average generation interval and the annual rate of inbreeding estimated by linear regression over time. In our case $t+1$ was chosen as the last birth year of our female reference population, i.e. 2007.

Second, $\Delta F$ was computed with the method by Gutiérrez et al. (2009). For each animal (i) from the reference cow population, the individual rate of inbreeding from its founders $\left(\Delta F_{i}\right)$ was computed as follows:

$$
\Delta F_{i}=1-\sqrt[E q G_{i}-1]{\left(1-F_{i}\right)}
$$

where $F_{i}$ is the coefficient of inbreeding of $i$ and $E q G_{i}$ is its individual equivalent generations traced as computed with Eq.1. The global rate of inbreeding $(\Delta F)$ was simply computed as the average of all individual rates of inbreeding $\left(\Delta F_{i}\right)$ of animals in the reference population.

The effective population size (Ne) was then computed for each breed with the two estimations of $\Delta F$ according to the classical formula:

$$
N e=\frac{1}{2 \Delta F}
$$

A third $N e$ was computed based on the increase in coancestry following the method by Cervantes et al. (2011). Considering the coancestry $c_{i j}$ between two individuals $i$ and $j$, their increase in coancestry $\Delta c_{i j}$ was calculated as follow:

$$
\Delta c_{i j}=1-\frac{E q G i_{i}+E q G j}{2} \sqrt{\left(1-c_{i j}\right)}
$$

As population sizes were too large to compute average coancestry on overall population, increases in coancestry were averaged over 100,000 pairs randomly sampled within each female reference population. Realized effective population size based on coancestries $N e_{c}$ was then computed as follow:

$$
N e_{c}=\frac{1}{2 \overline{\Delta c}}
$$

The coancestry coefficients within and between the three reference populations $\left(\mathrm{F}_{\mathrm{ref}} \mathrm{AM}\right.$ and $\mathrm{CBN}$ ) were computed and compared to the average coefficient of inbreeding (F) of the $\mathrm{F}_{\text {ref }}$ population. In addition, Wright's F-statistics $\left(F_{I S}\right)$ were estimated for the $\mathrm{F}_{\text {ref }}$ population by considering expected heterozygotie as (1-coancestry) and observed heterozygotie as (1-F) respectively (Leroy and Baumung, 2011). $\mathrm{F}_{I S}$ values were therefore calculated as:

$$
\text { Fis }=1-\frac{(1-F)}{(1-\text { coancestry })} \text {. }
$$




\section{Results}

\section{Pedigree depth}

Table 1 shows the number of equivalent generations traced which ranges from 5.3 (SIM) to 8.3 (NOR). Such values are close to other studies in dairy cattle, e.g. 7.2 for the Danish Holstein (Sørensen et al., 2005), and around 4.0 for the Irish Simmental (Mc Parland et al., 2007). Among the eight breeds under study the highest increase of $E q G$ in comparison with the first study by Maignel et al. (1996) was observed in the FRP breed (+108\%). The differences in EqG for this breed over the 1991/2007 period (equal to 3.1) is actually higher than the expected number of generations spent in the time period (equal to 2.5). This raise is undoubtedly due to the completion of pedigrees with information from other countries. For a given breed, the $E q G$ found for the males are always lower than the ones for the female breed populations (Table 1) with the exception of the CBN males for the HOL breed. This result is mostly explained by the average birth date of the different populations, which is lower for the male populations. The generation lengths varies from 5.6 (HOL) to 7.5 (TAR). They are the highest for the two French regional breeds (ABO and TAR).

The CBN bulls are older than the AM bulls in the HOL, MON and NOR breeds (Table 1). It is probably due to the fact that the dairy cattle collection was started as soon as 2001 with samples from these three breeds.

\section{Probabilities of Gene Origin}

Table 2 shows the results of different criteria derived from the theory of the probabilities of gene origin. For all the populations under study, the $f_{e}, f_{a}$ and $N_{50}$ can be considered as small and the contribution of the major ancestor as large when compared with other breeds under selection with similar pedigree depth such as sheep breeds ( $E q G$ between 4.6 and 8.1 in Danchin-Burge et al., 2010) or beef cattle breeds ( $E q G$ equal to 5.5 for the Limousin breed in Mc Parland et al., 2007). They are of the same magnitude as results from other studies on dairy cattle breeds (Sørensen et al., 2005).

Table 2 shows that the highest value of $N_{50}(18$, for FRP) is not found for the biggest reference population (which is the HOL breed), while the FRP is the second smallest breed ( Table 1). The male populations, both in situ and ex situ, have lower results in terms of probabilities of gene origins than the female reference populations. However the ratio between the variability genetic indicators for the female and male populations is much smaller than the ratio between the female and male populations size. 
Table 2: Analysis of the probabilities of gene origin for three categories of reference populations with both parents known: $F_{\text {ref }}=$ female born between 2004/2007, AM=active males, $\mathrm{CBN}=$ cryobank males

\begin{tabular}{|c|c|c|c|c|c|c|}
\hline Breed & $\begin{array}{l}\text { Total no. of } \\
\text { founders }\end{array}$ & $\begin{array}{l}\text { Effective no. } \\
\text { of founders }\left(f_{e}\right)\end{array}$ & $\begin{array}{l}\text { Effective no. } \\
\text { of ancestors } \\
\qquad\left(f_{a}\right)\end{array}$ & Ratio $f_{a} / f_{e}$ & $\begin{array}{l}\text { Contribution } \\
\text { of the top } \\
\text { ancestor }\end{array}$ & $\begin{array}{l}\text { No. of top contributing } \\
\text { ancestors accounting for } \\
50 \% \text { of the genes }\left(N_{50}\right)\end{array}$ \\
\hline HOL $\mathrm{F}_{\text {ref }}$ & 662,093 & 82 & 21 & $26 \%$ & 12.8 & 8 \\
\hline HOL AM & 868 & 67 & 14 & $21 \%$ & 13.2 & 5 \\
\hline HOL CBN & 1,925 & 102 & 15 & $15 \%$ & 14.5 & 5 \\
\hline MON F $F_{\text {ref }}$ & 132,874 & 65 & 19 & $29 \%$ & 15.1 & 7 \\
\hline MON AM & 528 & 57 & 14 & $25 \%$ & 16.2 & 5 \\
\hline MON CBN & 539 & 51 & 15 & $29 \%$ & 18.3 & 6 \\
\hline NOR F $F_{\text {ref }}$ & 106,206 & 81 & 23 & $28 \%$ & 11.8 & 8 \\
\hline NOR AM & 398 & 69 & 16 & $23 \%$ & 15.6 & 6 \\
\hline NOR CBN & 608 & 71 & 20 & $28 \%$ & 12.6 & 7 \\
\hline $\mathrm{ABO} \mathrm{F}_{\mathrm{ref}}$ & 9,208 & 41 & 15 & $37 \%$ & 18.1 & 5 \\
\hline $\mathrm{ABO} A M$ & 111 & 20 & 8 & $40 \%$ & 26.2 & 3 \\
\hline $\mathrm{ABO} \mathrm{CBN}$ & 215 & 26 & 10 & $38 \%$ & 23.5 & 4 \\
\hline $\mathrm{BSW} \mathrm{F}_{\mathrm{ref}}$ & 7,292 & 79 & 28 & $35 \%$ & 11.7 & 11 \\
\hline BSW M & 132 & 43 & 11 & $26 \%$ & 16.7 & 3 \\
\hline BSW CBN & 206 & 55 & 18 & $33 \%$ & 13.8 & 7 \\
\hline SIM F & 7,623 & 117 & 39 & $33 \%$ & 8.4 & 14 \\
\hline FRP $\mathrm{F}_{\text {ref }}$ & 5,210 & 209 & 51 & $24 \%$ & 5.9 & 18 \\
\hline TAR F $\mathrm{F}_{\mathrm{ref}}$ & 3,246 & 41 & 15 & $37 \%$ & 15.7 & 5 \\
\hline TAR AM & 140 & 29 & 11 & $38 \%$ & 18.1 & 4 \\
\hline TAR CBN & 260 & 33 & 12 & $36 \%$ & 16.1 & 4 \\
\hline
\end{tabular}


These results clearly suggest that a demographic parameter as simple as the actual population size of a breed is not enough to explain or predict the amount of genetic variability. The comparison between the male and female populations strongly suggest that the impact of $\mathrm{AI}$ on these breeds is so high that in the long run the genetic variability of the female population is an almost reflection of the genetic variability of a much smaller population, which is constituted by the AI bulls. In the case of the BSW breed, there is a bigger gap between the $f_{a}$ of the male and female populations than for the other breeds. It is probably due to the fact that farmers are also using AI bulls that are not selected in France, and therefore are not part of the CBN or the AM samples, which leads to more diversity in the female population. On the other hand, the extremely narrow basis of the male population of the ABO breed is noticeable and could lead to a reduction of the genetic variability of the female population.

Since the $80 \mathrm{~s}^{\prime}$ the values of $f_{a}$ and $N_{50}$ have decreased - sometimes drastically - for all breeds save for the SIM and the BSW (Fig. 1). Both parameters $\left(N_{50}\right.$ and $\left.f_{a}\right)$ are not exactly of the same nature and comparisons should be done intra-criteria. As an example, $N_{50}$ is more sensitive to the size of the reference population (Boichard et al., 1997). From the 1988-1991 to the 2004-2007 period, the $N_{50}$ was reduced by $53 \%$ in the NOR, $65 \%$ in MON and $72 \%$ in HOL. As for the $f_{a}$, it was reduced approximately by $40 \%$ in the $\mathrm{ABO}$ and NOR, $50 \%$ in the HOL and $70 \%$ for the MON. The TAR limited the loss of its already narrow genetic variability to $10 \%$. The case of the FRP is different since the pedigree knowledge of the breed has risen considerably between the 1988-1991 period and the following ones, thanks to the importation of new pedigrees for the breed in the SIG database. Results should be compared within the last three periods only.

The ABO, BSW, FRP and SIM breed have equivalent pedigree depth and current population size (Table 1), therefore the criteria we obtained based on their pedigree information is comparable without bias. The ABO appears (Table 2 and Fig. 1) as the breed that suffered the worst loss of genetic variability and that has the narrowest base - along with the smallest dairy breed under study, the TAR. On the contrary the results obtained in BSW, FRP and SIM show the highest values of the different indicators of genetic variability. When looking at the influence of various countries or breeds of origins over time (Fig. 2), we have some explanations on the differences found between these 4 breeds. The ABO shows a specific scenario with the introgression of Red Holstein genes in the late eighties and early nineties, with the proportion of Red Holstein genes reaching the maximum value of $6.7 \%$ in 1992 , then a constant decrease of this value since (2.2\% in 2007). As for the MON, the maximum proportion of Red Holstein genes was reached in 1990 (5.8\%) and is decreasing very slowly over the years since. Unlike what happened in the ABO breed, there is not a specific policy to eradicate the Red Holstein genes in the MON breed. 
Figure 1: Effective number of ancestors (Fa) and number of top contributing ancestors accounting for $50 \%$ of the genes (N50) over 4 different birth periods for the female reference population
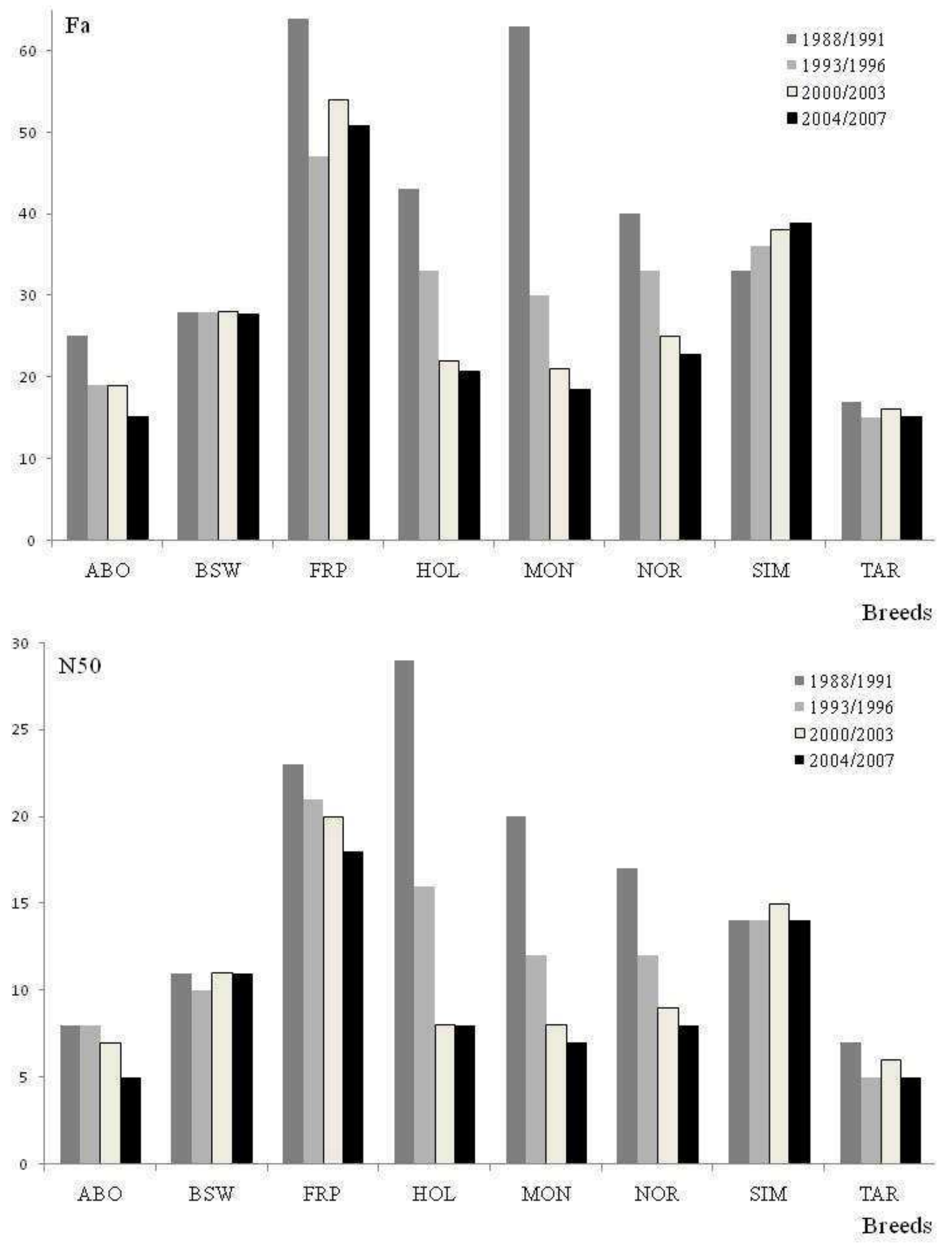
Figure 2: Change in the genes origin for the Abondance, Montbéliarde (2a), French Red Pied, French Simmental (2b) Holstein and Brown Swiss breeds (2c) for the females born with two parents known.

$2 a$
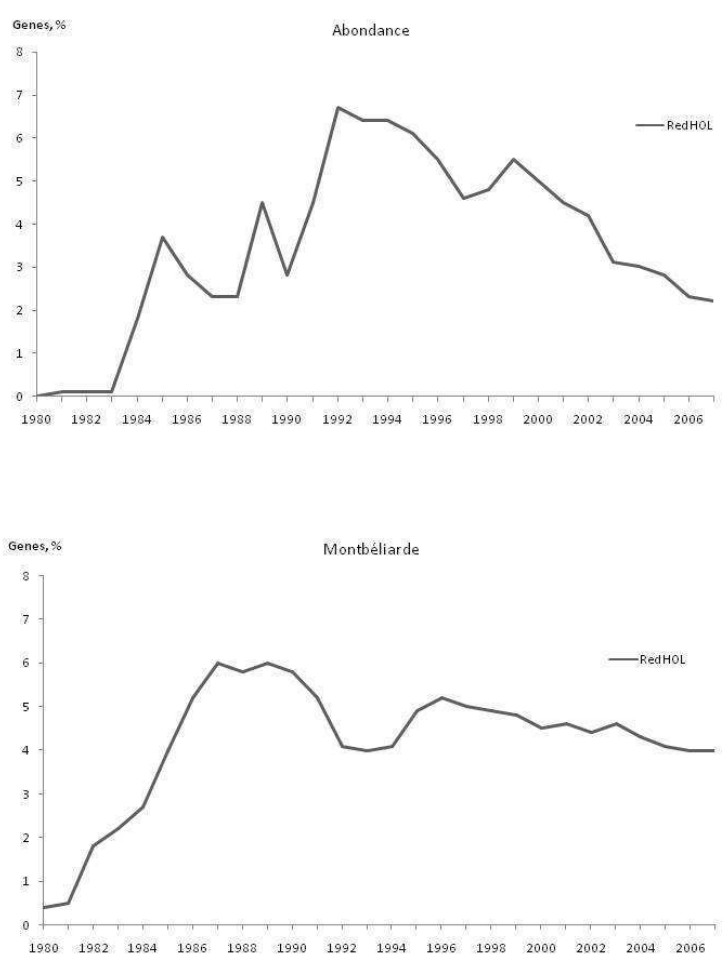

$2 b$
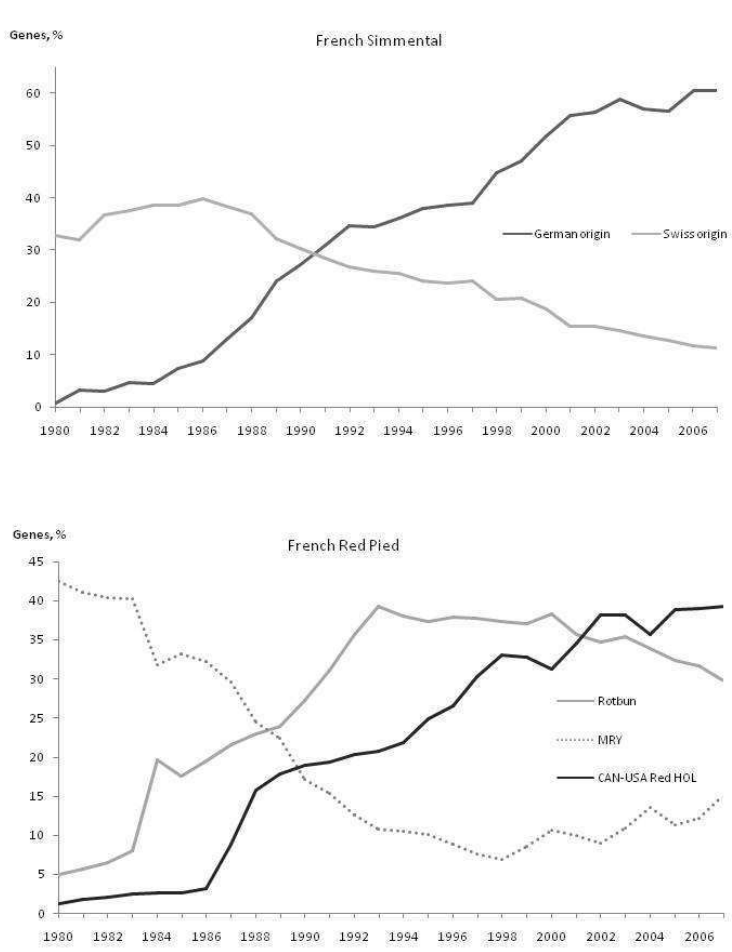

$2 c$
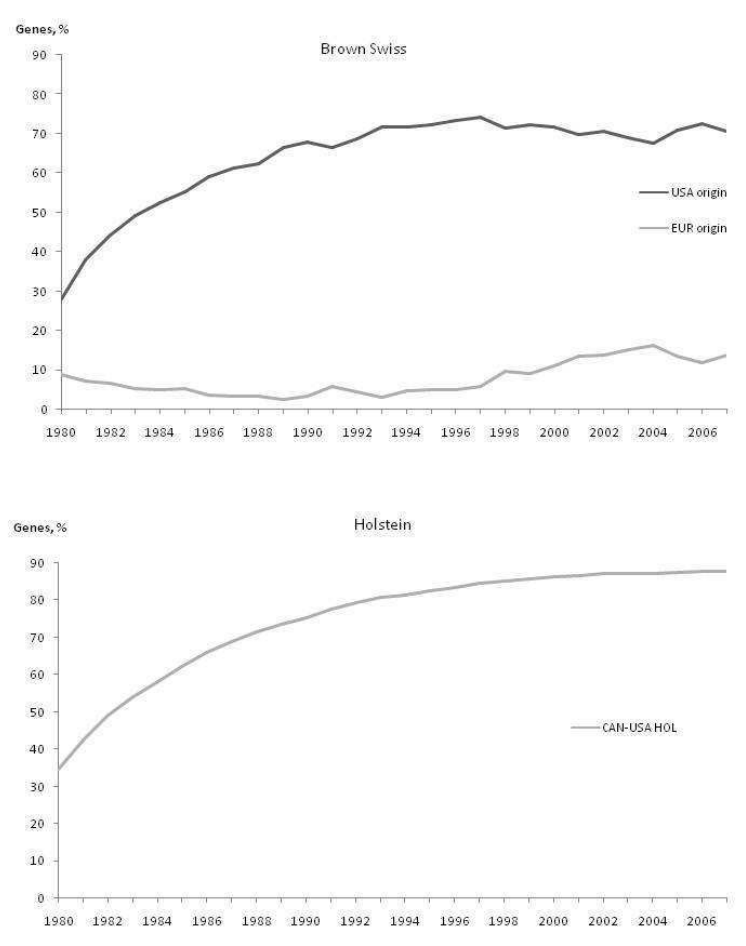
The SIM, FRP breeds and to a lesser extent the BSW breed, alternated the stocks of origin of the introgressed genes along the years (Fig. 2). Among the external origins that influenced the FRP breed, the Meuse-Rhine-Yssel breed (MRY) was the first used. Figure 2 clearly shows that the influence of the MRY went down as the influence of the Rotbun breed (from Germany) went up in the nineties, to be progressively replaced by the Red Holstein breed (from the US). The FRP appears now as a composite breed with external genes originating from the US Red Holstein (40\%), the Rotbun (30\%), and the MRY (15\%) breeds. As for the SIM, the first influence was the Swiss strain, which was progressively replaced by the German strain. In the case of the BSW it was thought in the nineties that the original European Brown Swiss genes were going to be replaced completely by US and Canadian genes. However since 1997, the percentage of European genes is steadily growing while the North American genes are stabilizing.

As for the HOL, the percentage of North-American genes in the French population is following an asymptotic curve which is the typical profile of any population where the males used are $100 \%$ from another origin.

\section{Inbreeding, effective population size and kinship}

For all breeds the effective population size calculated from the rate of inbreeding estimated by the Gutiérrez method is always higher than the one estimated by the classical approach (Fig. 3). The discrepancy is growing as the pedigree depth increases, with the exception of the FRP that shows the smallest difference (+23\%) after the SIM $(+15 \%)$ while it is the $6^{\text {th }}$ breed by the value of its pedigree depth. Our belief is that discrepancy is explained by the fact that this breed is the one that gained the most pedigree information since 1980 (+142\% between 1980 and 2007, results not shown). On the other hand the $N e_{c}$ calculated by the Cervantes method is always smaller than the one calculated by the Gutiérrez method, with the exception of the HOL. The comparison between the Ne calculated by the Cervantes method and the classical method shows no tendency.

With the classical approach, 5 breeds have an effective population size around 50 or lower, which means that they can be considered to be at risk according to the FAO recommendations (FAO, 1998). The picture is not as dark when considering the $\mathrm{Ne}$ calculated with the Gutiérrez or the Cervantes method, and the breeds are not ranked the same except for the breeds with the more genetic diversity i.e. the FRP, SIM and BSW. With the classical approach, the ABO is the breed with the lowest Ne, followed by the TAR, then the MON, HOL and NOR breeds (Fig. 3). Differences between methods, as already observed in the case of two horse breeds by Verrier et al. (2011), are due to the properties of each estimator. The classical method is calculated on a fixed period (with eventual biases due to the choice of the period) while the Gutiérrez approach takes into account the whole pedigree knowledge (with eventual biases due to the disequilibrium in the pedigree knowledge of the sire and dam pathways). 
Figure 3: Values of Ne calculated with three differeFigure 3. Valunt methods for eight French dairy cattle breeds, by growing Ne (Gutiérrez method)

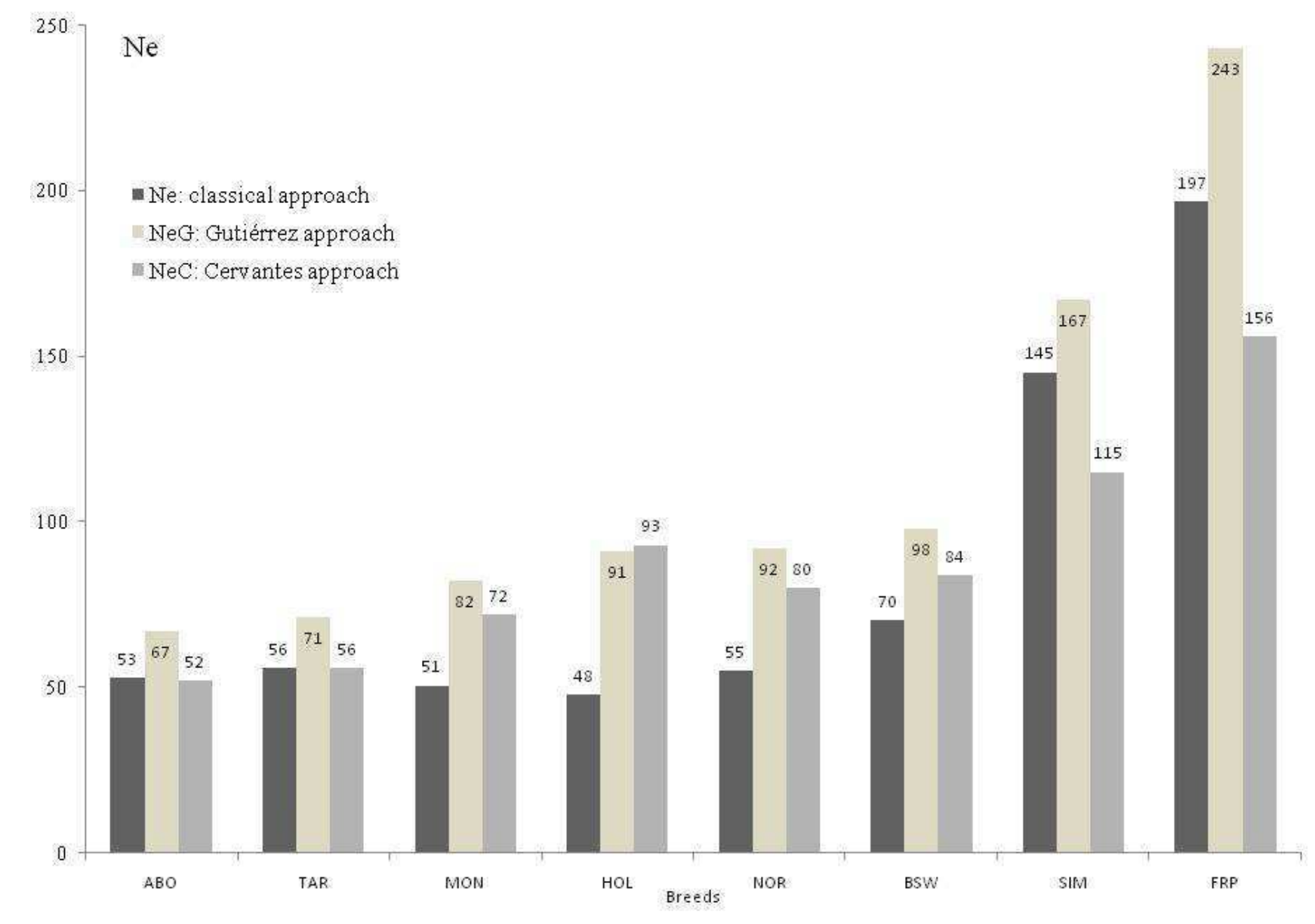


Table 3 shows the average coefficients of kinship computed between the different populations. The highest values for the $\mathrm{F}_{\text {ref }}$ populations are found for the NOR (5.1\%), MON (5.0\%) and TAR (4.9\%) breeds. The value calculated for this last breed is lower in comparison with the NOR and MON breeds, probably because of its lower $E q G$. The FRP and SIM breeds have the lowest $\mathrm{F}_{\text {ref }}$ kinship values (respectively $1.9 \%$ and $2.3 \%$ ). As for the parameters of probability of gene origin, the results found from the female populations are quite close to the ones found for the male populations. Also, the kinship between AM is always higher than the kinship between CBN males. This result would lead us to believe that the Cryobank managed to preserve some of the male genetic variability of the dairy cattle breed, by sampling original bulls according to differences in their pedigrees or their extreme index values, despite of the small size of the collection in some breeds. Finally, as shown in Table 3, all the $\mathrm{F}_{\text {IS }}$ values are negative, which would imply that there is no sub structure in the different breeds (no Wahlund effect).

\section{Discussion}

At a time where dairy selection is undergoing a revolution with the genomic selection, it was appropriate to assess the genetic variability of the main French cattle breeds. Since the first assessment of these breeds' genetic variability (Maignel et al. 1996), a French National Cryobank has been set up as a way to secure the genetic variability of our selected breeds. This article is also an opportunity to compare the genetic variability of the ex situ and in situ populations and see if the sampling used for the Cryobank is a successful method to preserve the genetic diversity of these breeds.

Various studies were published on the genetic variability of livestock species (on dogs: Leroy et al. 2006; on sheep: Danchin-Burge et al. 2010; on beef cattle: Gutiérrez et al. 2003). Some studies specifically deal with dairy cattle (Baumung et al., 2003; Koenig et al. 2006, Mc Parland et al. 2007; Sørensen et al. 2005). However most of them are restricted to the analysis of inbreeding. Yet Boichard et al. (1997) as well as Baumung et al. (2003) warned about the sensitivity of this parameter to incomplete pedigrees. According to the same study, the advantage of the theory of the probability of gene origin to assess the genetic variability of a breed is its robustness in comparison with methods based on probability of identity computation (inbreeding). Another way to limit bias due to incomplete data is to compare breeds based on their inbreeding rates or, even better, their rate of coancestry. The results found by the Gutiérrez (inbreeding rates) and Cervantes (coancestry rates) methods are showing some discrepancies. The smallest differences are found for the biggest breeds (HOL, MON, NOR), and could probably be explained by their larger size. Under the assumption of random mating with an infinite population size in equilibrium, inbreeding and coancestry are equal. In the case of smaller populations, in random mating conditions, the percentage of mating between related animals (such as full sibs) is increased. Therefore, any efforts from the farmers to avoid mating between related animals have an impact that can be traced by a growing difference (as the number of reproducers decreases) between average coancestry and inbreeding, such as what is recorded for the SIM and FRP mostly. 
Table 3: Average inbreeding level (F) and Wright's F-statistics ( $\left.F_{I S}\right)$ in the female reference population. Average coefficient of kinship (K) between and within the female reference populations ( $F_{\text {ref }}$ ) and the male populations (CBN and AM). All $F$ and $\mathrm{K}$ values are given in $\%$.

\begin{tabular}{|c|c|c|c|c|c|c|c|c|}
\hline \multirow{2}{*}{ Breed } & \multirow[b]{2}{*}{$\mathrm{F}$} & \multirow[b]{2}{*}{$\mathrm{F}_{\text {IS }}$} & \multicolumn{5}{|c|}{$\mathrm{K}$} & \multirow[b]{2}{*}{$\mathrm{AM}^{*} \mathrm{CBN}$} \\
\hline & & & $\mathrm{F}_{\text {ref }} * \mathrm{~F}_{\text {ref }}$ & $\mathrm{F}_{\mathrm{ref}}{ }^{*} \mathrm{CBN}$ & $\mathrm{F}_{\mathrm{ref}}{ }^{*} \mathrm{AM}$ & $\mathrm{CBN}^{*} \mathrm{CBN}$ & $\mathrm{AM}^{*} \mathrm{AM}$ & \\
\hline Holstein & 3.8 & -0.003 & 4.1 & 4.7 & 5.0 & 6.4 & 6.6 & 5.8 \\
\hline Montbéliarde & 3.8 & -0.013 & 5.0 & 5.2 & 5.2 & 5.9 & 6.4 & 5.8 \\
\hline Normande & 4.0 & -0.012 & 5.1 & 5.3 & 5.6 & 5.6 & 6.4 & 5.9 \\
\hline Abondance & 3.7 & -0.010 & 4.7 & 6.4 & 6.6 & 7.5 & 9.3 & 9.0 \\
\hline Brown Swiss & 2.6 & -0.009 & 3.5 & 4.0 & 4.5 & 4.7 & 5.7 & 6.3 \\
\hline French Simmental & 1.4 & -0.009 & 2.3 & I & 2.3 & l & 2.8 & l \\
\hline French Red Pied & 1.1 & -0.008 & 1.9 & l & 2.2 & 1 & 2.0 & I \\
\hline Tarentaise & 3.4 & -0.016 & 4.9 & 5.1 & 5.3 & 5.3 & 5.9 & 6.4 \\
\hline
\end{tabular}


The first assessment of the genetic variability of these eight French selected dairy cattle breeds was already stating the narrow basis of these breeds (Maignel et al., 1996). This statement is shared worldwide for dairy cattle breeds where AI is used as the main way of reproduction, and where the amount of AI doses per bull reaches easily thousands, or even the tens of thousands for the HOL breed. On the basis of these preliminary results, implementations of procedures to minimize inbreeding in sire evaluation programs (Meuwissen, 1997, Colleau et al., 2004) were developed. Since there is an awareness of the dramatic loss of genetic variability of these breeds, it is usually assumed that the setting up of specific genetic programs (such as "VARGEN" VARiabilité GENétique genetic variability - a French program based on the Colleau et al. 2004 method) has slowed down the process. As we have just seen, in light of our results there is every reason to believe that the genetic variability of our main dairy cattle breeds are still quickly eroding, with the exception of three breeds (BSW, FRP, SIM).

One explanation of the loss of genetic variability monitored in the NOR, HOL, MON, $\mathrm{ABO}$ and TAR breeds is the simple fact that their pedigree information was built up over the years. However it cannot be the only explanation since the loss monitored in the three remaining breeds (BSW, SIM, FRP) is not as stringent. Furthermore, Baumung et al. (2003) showed that when the equivalent generation level reached a level of 5, an increase in the pedigree information has a small impact on inbreeding evaluation. A more likely explanation would be that the drastic bottlenecks created in the nineties, with the massive use of a single or a few AI bulls (e.g. BOISLEVIN in the MON breed who sired $46 \%$ of the progeny bulls born in 1993 and 1994 or DIAMETRE in the NOR breed who sired 45\% of the progeny tested bulls born in 1994 and 1995- Le Mezec, 2010) are still having side effects, since these bulls are now the grand-fathers or the greatgrand fathers of most AI bulls used today. Also it was expected that the VARGEN program would have long term effects: the first generation of AI bulls created with this mating plan is only now being used, which means that their offspring were not included in the population under study.

The better results monitored for the BSW, FRP and SIM breeds are multi-factorial. These breeds are using AI bulls from various origins and countries, and each breeding program in the different country have their specificities, which is not the case anymore for the HOL breed for example. As an example, for the BSW, it was expected that following what was happening with the Dutch Friesian that got completely introgressed by the North American Holstein (Vollema et al., 1996), the breed would become a NorthAmerican Brown Swiss. Our results show that as today this is not the case. Also, all these breeds went through major change of orientations over the years, as we saw previously (Fig. 2), which favored their genetic variability. The important factor is to alternate gene origins without forcing the elimination of genes of a particular origin. As an example in the ABO breed, in the nineties, Red Holstein genes were introgressed in order to increase the production level and genetic variability of the breed (Fig. 2). However the presence of half-bred bulls was not well accepted by the farmers of the breed, which lead a few years later to the riddance of all AI bulls with Red Holstein genes. By doing so, another bottleneck was created in a breed that already had a narrow genetic variability, leading to the low results described in this article. 
Outcrossing with other breeds is often offered as way to solve inbreeding effects in a finite population (Blöttner et al. 2011). However it will imply a very difficult organization, with a rotation on several breeds and finding ways to keep purebred nucleus flocks. Also we just showed that all French selected dairy breeds have quite a low genetic variability, and such results are probably identical in other dairy cattle breeds. The outcross population would be inbred quite rapidly (if no specific managements that include loss of genetic diversity as an integrated control parameter are implemented), all the more so since lot of dairy cattle breeds have used the Holstein breed to increase their dairy performance, as we showed in the FRP or ABO breed. Another way out is by using the large array of existing tools to preserve genetic variability, which goes from following quite simple demographic rules all the way to quite sophisticated optimization methods (Colleau et al. 2004).

Finally, we showed that the sampling method used for the French National Cryobank is quite efficient despite the fact it is a fairly new tool, since all collections have a lower kinship with female than the AM * female kinship (Table 3). However kinship is quite higher than the kinship of the female population, which could be already considerate as high, so it seems crucial to protect the last straws from old AI bulls that might still exist as already stated in Danchin-Burge et al. (2011).

We have shown that the indicators of genetic variability of our eight main dairy cattle breeds have decreased drastically since the first study (1996) that was done on the subject, with the exception of 3 breeds that have recently stabilized their indicators. Given the clarity of these results, there is every reason to believe that the main bottlenecks that were created in the nineties still have a negative impact on the population of cows that was recently born (2004/2007). On the other hand, it appears likely that by varying the origins of their AI bulls, the Brown Swiss, the French Red Pied and the French Simmental breeds, have slowed down the process. We are also presently convinced that the effects of the VARGEN management plan cannot yet be assessed, as the offspring of the first AI bulls created by this program were born after the population under study.

With the classic selection schemes, the genetic values of the progeny tested bulls were known very precisely but this accuracy had a high financial cost. For these reasons lots of doses were sold for a few bulls, the "stars" of the progeny testing programs. With the arrival of genomic selection, farmers have now access to a wider panel of bulls, whose genetic values are not as accurate as for the classic schemes. In some cases farmers are buying a "pack" of sires for which the individual breeding values are not made available to farmers, which should therefore limit the popular sire effect and limit the creation of new bottlenecks. 


\section{Acknowledgments}

The authors wish to thank the staff and the breeders of the different breed associations for their insight on the history and management of their breeds. We are also grateful to the editor and three anonymous referees for helpful comments on the manuscript.

\section{References}

Baumung, R., Sölkner, H. (2002) Analysis of pedigrees of Tux-Zillertal, Carinthian Blond and Original Pinzgau cattle population in Austria. J. Anim. Breed. Genet., 119, 175181.

Baumung, R., Sölkner, J. (2003) Pedigree and marker information requirements to monitor genetic variability. Genet. Sel. Evol. 35, 369-83.

Blöttner, S., Heins, B.J., Wensch-Dorendorf, M., Hansen, L.B., Swalve, H.H. (2011) Brown Swiss $\times$ Holstein crossbreds compared with pure Holsteins for calving traits, body weight, backfat thickness, fertility, and body measurements. J. Dairy Sci., 94, 1058-1068.

Boichard, D. (2002) PEDIG: a fortran package for pedigree analysis suited for large populations. In: Proceedings of the 7th World Congress of Genetics Applied to Livestock Production, Montpellier (France), 19-23 August 2002, CD-Rom, comm. no 28-13, Montpellier, France.

Boichard D., Maignel L., Verrier E. (1997) Value of using probabilities of gene origin to measure genetic variability in a population. Genet. Sel. Evol. 29, 5-23.

Cervantes, I., Goyache, F., Molina, A., Valera M., Gutiérrez, J.P. (2011) Estimation of effective population size from the rate of coancestry in pedigreed populations J. Anim. Breed. Genet. 128, 56-63.

Colleau, J.J., Moureaux, S., Briend, M., Béchu, J. (2004) A method for the dynamic management of genetic variability in dairy cattle. Genet. Sel. Evol. 36, 373-394.

Danchin-Burge, C., Verrier, E., Moureaux, S., Tixier-Boichard, M. (2006) Sampling protocols and review of the French National Cryobank collections. In: Proceedings of the 8th World Congress of Genetics Applied to Livestock Production, Belo Horizonte MG, (Brazil), 13-18 August 2006, CD-Rom, comm. no 33-3 Belo Horizonte MG, (Brazil).

Danchin-Burge, C., Palhière, I., François, D., Bibé, B., Leroy, G., Verrier, E. (2010) Pedigree analysis of seven small French sheep populations and implications for the management of rare breeds. J. Anim. Sci., 88, 505-516.

Danchin-Burge, C., Hiemstra, S.J., Blackburn, H. (2011) Ex situ conservation of Holstein-Friesian cattle - Comparing the Dutch, French and USA germplasm collections. J. Dairy Sci., 94, 4100-4108.

Falconer D.S., Mackay T.F.C. (1996) Introduction to Quantitative Genetics, Ed 4. Longman's Green, Harlow,Essex, UK.

FAO (1998) Secondary Guidelines for Development of National Farm Animal Genetic Resources Management Plans. FAO, Rome, Italy. pp. 63.

Fernandez, J., Villanueava, B., Pong-Wong, R., Toro, M.A. (2005) Efficiency of the use of pedigree and molecular information in conservation programs. Genet., 170, 1313-1321.

Gutiérrez, J.P., Altarriba, J., Díaz C., Quintanilla, R., Cañón, J., Piedrafita, J. (2003) Pedigree analysis of eight Spanish beef cattle breeds. Genet. Sel. Evol., 35, 43-63.

Gutiérrez, J.P., Cervantes, I., Goyache, F. (2009) Improving the estimation of realized effective population sizes in farm animals. J. Anim. Breed. Genet. 126, 327-332.

Kim, E.S., Kirkpatrick, B. W. (2009) Linkage disequilibrium in the North American Holstein population. Anim. Genet., 40, 279-288. 
Koenig, S., Simianer, H. (2006) Approaches to the management of inbreeding and relationship in the German Holstein dairy cattle population. Livest. Sci., 103, 40-53.

Lacy, R.C. (1989) Analysis of founder representation in pedigrees: founder equivalents and founder genome equivalents. Zoo Biol., 8, 111-123.

Le Mezec, P. (2010) Utilisation des ressources paternelles et maternelles dans les programmes de sélection des races montbéliarde, normande et prim'holstein. Période 1996-2008. Institut de l'Elevage, Paris, France.

Leroy, G., and Baumung, R. (2011) Mating practices and the dissemination of genetic disorders in domestic animals, based on the example of dog breeding. Anim. Genet., $42,66-74$

Maignel, L., Boichard, D., Verrier, E. (1996) Genetic variability of French dairy breeds estimated from pedigree information. Interbull Bull., 14, 49-54.

Mattalia, S., Barbat, A., Danchin-Burge, C., Brochard, M., Le Mézec, P., Minéry, S., Jansen, G., Van Doormaal, B., Verrier, E. (2006) La variabilité génétique des principales races bovines laitières françaises: quelles évolutions, quelles comparaisons internationales ? Renc. Rech. Rum., 13, 239-246.

Mc Parland, S., Kearney, J.F., Rath, M., Berry, D.P. (2007) Inbreeding trends and pedigree analysis of Irish dairy and beef cattle populations. J. Anim. Sci., 85, 322-331.

Meuwissen, T.H.E. (1997) Maximizing the response to selection with a predefined rate of inbreeding. J. Anim. Sci., 75, 934-940.

Meuwissen, T.H.E., Luo, Z. (1992) Computing inbreeding coefficient in large populations. Genet. Sel. Evol. 24, 305-313.

Moureaux S., Boichard D., Verrier E., (2000) Utilisation de l'information généalogique pour l'estimation de la variabilité génétique de huit races bovines françaises d'extension nationale ou régionale. Renc. Rech. Rum., 7, 149-152.

Philipsson, J., Forabosco, F. Jakobsen, J.H. (2009) Monitoring sustainability of international dairy breeds. InterBull. Bull., 40, 287-291.

Sørensen, A.C., Sørensen, M.K., Berg, P. (2005) Inbreeding in Danish Dairy Cattle Breeds. J. Dairy Sci., 88, 1865-1872.

Van Doormaal, B., Miglior, F., Kistemaker, G., Brand P., (2005) Genetic diversification of the Holstein breed in Canada and internationally. Interbull Bull., 33, 93-97.

Verrier, E., Tixier-Boichard, M., Bernigaud, R., Naves, M. (2005) Conservation and values of local livestock breeds: usefulness of niche products and/or adaptation to specific environments. Anim. Genet. Resources Info., 36, 21-31.

Verrier, E., Leroy, G., Blouin, C., Mériaux, J.C., Rognon, X., Hospital, F. (2011) Comparing methods for estimating the effective population size from pedigree or molecular data: a case study on two French draught horse breeds. Genet. Sel. Evol. (submitted).

Vollema, A.R., Groen, A.F. (1996) Genetic correlations between longevity and conformation traits in an upgrading dairy cattle population. J. Dairy Sci., 80, 30063014. 